\title{
Hybrid Solidarity Arek Surabaya Solidarity Shift in the Post-Reformation Era in Indonesia
}

Agustinus Ryadi

Universitas Katolik Widya Mandala Surabaya, Indonesia

ryadi@ukwms.ac.id (iD https://orcid.org/0000-0001-8609-1545

This paper deals with the cultural shift of the Arek Community in Surabaya after the reformation era (Era Reformasi) in Indonesia. Cultural phenomena are unique, and due to the uniqueness of a culture, it is sometimes difficult to understand and even misleading. To help readers understand the idea presented in the paper, some keywords must be clarified.

In Hebrew, arek is a boys' name which means "mountain strength" (Yin, 2010). In Javanese the word, especially in Surabaya dialect, arek means young people or youth which is filled with regional enthusiasm and heroic spirit. The connotation behind this word is brave and egalitarian (Trinarso, 2019). Another word associated with arek is bonek, which is the acronym of bondonekat (bondo means belongings or capital, nekat means brave). Thus, bonek means no capitals but brave. Bonek was born because of communal solidarity. Bonek presence in social connection, especially in the world of football. It is a new magnet in the enthusiasm of Indonesian football, and Bonek comes itself.

The other keyword to be clarified is culture. Culture refers to a large and diverse set of mostly intangible aspects of social life. According to sociologists, culture consists of the values, beliefs, language systems, communication, and practices that people share in common and can define them as a collective. Culture also includes the material objects common to that group or society and are passed from generation to generation. Culture is relative, meaning that each community has its own specific culture. In addition, culture is in a constant state of change 
because of many factors, such as education, wars, and contact with other cultures (Ngadiman, 2008).

Etymologically, the word Surabaya comes from the Javanese suraingbaya, meaning "bravely facing danger." Surabaya is the capital of the East Java province of Indonesia, and Surabaya is the second biggest city in Indonesia. The town has been reckoned as the city of the hero since the battle against colonial 1n 1945.

Based on the study conducted by Sholihatin (2013) the Arek culture is one of the subcultures in East Java besides Mataraman, Pandalungan, and Madura. Arek culture is based in Surabaya, even though it originated from a colonial-era nicknamed "Surekoyo Arek-Arek" community. Arek culture has regional bases spread in Surabaya, Sidoarjo, Malang, Gresik, Mojokerto, Jombang, part of old Kediri, and part of Blitar. Arek culture derived from the village community in Surabaya, which became the home of the people of Surabaya with migrants from various regions in East Java such as Pare, Madura, Jombang, Tuban, and several areas outside East Java. This happened not entirely natural because basically, it was related to the political strategy of regional regulation in the era of Dutch colonialism, which localized ethnic groups in separate villages (Arab villages or Chinese villages) so that the Surabaya people lived separately and built their own identities. Sholihatin (2013) considered that the identity of the arek Surabaya had different characteristics compared to other arek communities such as the arek Malang, arek Sidoarjo, arek Gresik, arek Mojokerto, etc. The difference in the attributes of Arek Surabaya is influenced by the position of Surabaya as the center of trade and the struggle for independence, and the center of government in East Java. The city of Surabaya determines the patterns of social relations, education, livelihoods, languages, arts, and religious systems that are typical of the Surabaya arek. However, their cultural characteristics are more or less similar.

Many studies on Arek Surabaya often identify Arek Surabaya as "emotional and easily ignited" community groups, "rebels and vandals," "terrorist gangs," and even their actions are considered "uncivilized." This is inseparable from the effort to compare the lifestyle of the people of Surabaya and the tradition of the Mataraman Palace, which dominates 
the Yogyakarta, Central Java, and other regions with the thick tradition of the Javanese Palace (Trinarso, 2019). Followers of the Keraton style are judged to be more subtle in language and actions, more organized in style, and hence more civilized. This research is considered by Palmos (2016) as a Western lens in seeing Arek Surabaya's culture. In other eyes, historians also see Surabaya as a symbol of resistance to feudalism, be it royal or colonial feudalism. The solidarity built in Surabaya in the past can manifest fierce resistance against the great powers from outside. Rebellion or insubordination by the people of Surabaya is based on the spirit of solidarity to fight together for life and injustice. One of the most famous stories of the solidarity of the people of Surabaya is their tireless resistance against the Dutch army in the Indonesian war of independence. The Surabaya people, who called themselves Arek Surabaya, did not care about their religious, ethnic, racial background and ownership in the war. A common goal united them in maintaining the independence that Indonesian leaders had proclaimed in Jakarta on August 17, 1945. The unity of the community based on this common goal was encompassed in the various virtues of Arek Surabaya, which appeared in their shared way of life. Over time, this kind of solidarity has changed, especially when the democratization flow has become stronger in Indonesia. One of the moments of democratization is the reformation of 1998. Along with democratization, it appears that solidarity is increasingly fading, and social ties based on solidarity are manifested in different forms of appearance in the lives of the Arek Surabaya community.

Capital flows in post-reformation, globalization, and the presence of many value preferences in democracy seem to have produced many societal changes. Simply put, we can recognize these changes through a process of physical change (infrastructure, buildings, housing, apartments, new settlements, shops, factories) in Surabaya.

As forming social ties, solidarity is not just present in society. There are various processes in the course of the history of society that bring the community to a specific form of solidarity in accordance with the goals to be achieved by that community. The meaning of solidarity is something dynamic and experiencing shifts, and various factors can influence changes in the definition of solidarity. 
A community can be formed because of a collection of individuals who desire to live together. The desire to live together is closely related to community attachment based on solidarity. The basis of shared life can be identified through social behavior to interact with one another and give birth to feelings of being one with the other. It is this feeling that unites society that we can call solidarity. Solidarity has diverse and dynamic forms. Community understanding of solidarity is the key to recognizing the basic social life of a community.

The character and tendency of the behavior of a society / social group will be strongly influenced by the meaning of solidarity. A deep understanding of the shift in solidarity will help policy analysts and social researchers determine the proper steps and policies in dealing with the dynamics of society. Therefore, we value this change in the meaning of Arek Surabaya's solidarity as something important to study because an adequate understanding of changes in the definition of solidarity will help us recognize the factors driving solidarity change and how to treat it in the future.

As forming social ties, solidarity is not just present in society. There are various processes in the course of the history of society that bring the community to a specific form of solidarity in accordance with the goals to be achieved by that community. The meaning of solidarity is something dynamic and experiencing shifts. Various factors can influence changes in the definition of solidarity. This study would like to explore further the factors that influence changes in the form of solidarity in the Arek Surabaya community. A community can be formed because of a collection of individuals who desire to live together. The desire to live together is closely related to community attachment based on solidarity. The basis of shared life can be identified through social behavior to interact with one another and give birth to feelings of being one with the other. It is this feeling that unites society that we can call solidarity. Solidarity has diverse and dynamic forms. Community understanding of solidarity is the key to recognizing the basic social life of a community. The character and tendency of the behavior of a society or social group will be strongly influenced by the meaning of solidarity. A deep understanding of the shift in solidarity will help 
policy analysts and social researchers determine the proper steps and policies in dealing with the dynamics of society. It is then imperative to seek the direction of solidarity shift in the arek Surabaya community after the reformation era in 1998. The factors that influence changes in solidarity in the Arek Surabaya community should also be revealed.

\section{Conceptual Framework}

The present study was based on social solidarity. In this part, the concept social of solidarity and solidarity shifting as well as the types of solidarity mechanic and organic categories) are reviewed. A highlight of solidarity among arek Surabaya is presented to give a picture of the characteristics of this community

\section{The Concept of Solidarity and solidarity Shifting}

From the history of conceptual development, the word "solidarity" is etymologically understood from one of the legal obligations in the ancient Roman Empire called obligatio in solidum. Bayertz (1999) said that this law states that if a community member has certain obligations, that obligation binds him individually and binds all members of the community to which he is bound. For example, if someone is indebted to the creditor, who is bound to the obligation to pay the debt is not only the debtor but those who are bound in the community where he lives. This explains how particular family or community members can exert social pressure on anyone who has not carried out their obligations to others outside the community because if the obligation is not carried out, the community members will also feel obliged. Likewise, demands from others outside the community to give rights to friends in the community are no longer fought only by friends who have taken away their rights but become collective struggles.

Although this kind of legal principle definitively ends in the Modern era (starting from the Renaissance, around the 1500s), the idea of a shared 
obligation based on communal solidity still lives as a concept that underlies community life. As Modern society becomes increasingly individualistic and feudalism increasingly unacceptable, the idea of solidarity is maintained in a different form. This is influenced by the development of an increasingly industrial character in the Modern era. According to Bayertz (1999), this kind of thinking was revealed by Emile Durkheim.

In his thesis regarding social solidarity, Durkheim explains that individuals are influenced by social facts (Ritzer, 2007). Those social facts include languages, building, and ethics. According to Durkheim, being outside of individuals and yet they are powerful in shaping the individual. Social facts can be both material and nonmaterial. Material social facts are visible, such as buildings, while nonmaterial facts are difficult to see, but we know they exist as a society. The nonmaterial facts are customs, culture, and norms of any given society (Ritzer, 2007).

Derpmann (2009) posits solidarity can be understood as moral care and responsibility for the rights and welfare of others. In solidarity, respect and moral responsibility for the rights and interests of others are directed locally in a community where people are bound to one another. Here, each community member will voluntarily give his fellow community members things needed even if he has to sacrifice himself. In connection with this obligation, basically, the bond of solidarity is always communal and not universal. Philosophically, Andreas Göbel and Eckart Pankoke, "Bonds and Bounds of Solidarity” in Bayertz (1999) researchers from the Sociological department at the University of Essen, Germany, say that this is not only related to bonds that are inherently attached to a specific group of people and gives them an invisible "bond" but encourages them to adjust to each other. This process in its development is also related to the values that are fought for together that are relevant to the meaning of life that unites them to one another.

Modern industry requires many people from various places to gather in a certain area, working at certain times in a certain way. Modern industrial growth is changing the map of the population of the community from previously in a particular community that is bound by various kinship ties based on the family into new communities that are more technical (for industrial interests) and pragmatic (to meet the needs of 
individual life, not family/community). Thus, the idea of solidarity no longer rests on primordial ties, which from the beginning bind a person based on cultural and kinship ties but instead rests on the intensity of encounters and the common goal of living together to be achieved together within a certain scope.

In European history itself, this kind of solidarity generally manifested itself in the past during the French Revolution. This revolution is a form of solidarity with French people who feel oppressed and a form of resistance against the oppressors. This kind of solidarity in different forms also continues to be voiced by the Marxists, who manifest themselves in the form of the communist government. Solidarity in the Modern period above gives an emancipatory meaning of solidarity. Solidarity is formed from situations of suffering, injustice, and oppression. Faced with this situation, the community is driven to make changes. Solidarity is demonstrated through actions and ideas that aim to liberate the community. In this regard, Durkheim (1984, p. 105-106) concludes that the strength of social ties is determined by three conditions: First, the relationship between collective conscience and individual awareness. Social solid links will increasingly influence/shape individuals more totally. Second, the average intensity of the institutionalization of collective consciousness. The relationship between the level of shared consciousness and the individual is assumed to be in the same direction as the intensity level of the two related. When the level of intensity is high, the collective awareness will have more influence on the individual the more energy he has to cooperate. Conversely, if the intensity is weak, the capacity to direct individuals toward collectivity is also weak. Thus, individuals will quickly go their way, and solidarity will become less intense.

Durkheim (1984) argues that because of these conditions, consensus needs to be made as perfect as possible; every awareness must have one breath. Conversely, the more general and not necessarily (strictly) rules of behavior and thoughts, the more individuals apply the rules for some instances. But such reflective thinking cannot arise without conflict, and centrifugal tendencies can continue at the expense of social cohesion and harmony in the way society works. 
At the end of the Division of Labor, Durkheim described that in modern society, solidarity still exists and is shifted to another form. The emergence of the division of labor allows people to complement, rather than conflict with, each other. Furthermore, an increased division of labor results in greater efficiency with the result that resources are growing, the competitive situation will change to a more peaceful situation (Pasaribu, 2012). Durkheim argues that solidarity in modern society has changed shape but has not disappeared (Pasaribu, 2012). Shared experiences and shared beliefs no longer unite modern society. Instead, they are united through their differences, as long as they are allowed to develop in a way that encourages interdependence. The key to community development is social justice (Pasaribu, 2012).

\section{Organic Solidarity and Mechanical Solidarity}

From the literature of sociology written by experts in the fields, Durkheim classified two types of solidarity according to the type of society. Mechanical solidarity happens in traditional and small-scale societies where members share ethnicity, work, education, religious training, and lifestyle. There is also kinship, family, and social ties with mechanical solidarity. Organic solidarity happens in modern societies, bringing people together based on a division of provision and need where individuals depend on each other for the lifestyle. Organic solidarity is based upon diversity when depression, economic crisis, and personal upheaval are experienced. Despite its popularity, the distinction between organic and mechanical solidarity has received a lot of criticism (Thijessen, 2012).

Communities live in tension and a combination of the pursuit of economic interests (individual) through transactional work and social life (social). In this case, there is a mixture of two types of solidarity. On the one hand, the community supports organic solidarity. In an increasingly specific and differentiated work model that seems transactional individuals actually have solidarity. The solidarity that is built is solidarity which Durkheim (1984) calls organic solidarity. Indirectly, 
through transactional work and individually, communities meet their needs more effectively and efficiently to enable a prosperous and abundant state. However, the organic solidarity model will not truly become solidarity if the community does not interpret its work as part of community life. In capitalist societies, the tendency to interpret work as an effort to obtain material economic wealth that is individual is more prominent than to interpret work as part of the social process and selfactualization (in society). Work is meant as a means of making money. When work is always interpreted as "making money," people tend to act strategically without limits. Often what is being pursued is not the maximum work output but how to get the most money possible with the least effort. The logic of capitalism, which is not accompanied by discourse about the meaning of work as part of solidarity, threatens the primacy of the people who work and can have an effect on the work that is less than the maximum.

On the other hand, despite living in mechanical solidarity. Even though they have experienced the process of modernity, cultural values and traditions in society are not completely lost. Although some traditions have transformed, there is still social life in regional communalism as in the past. In the Surabaya community, this is evident in the village activities that are still being carried out, such as arisan, patrolling, mutual assistance, helping each other in celebration, etc. The community carries out these two kinds of solidarity simultaneously.

Religion has a unique place between these two types of solidarity. Religion has the potential to contribute to making this mechanical solidarity persist, even though the interpretation of radical religion can also form other solidarity contexts that are similar to mechanical solidarity. Interestingly, in organic solidarity (especially in Indonesia), religion also has the potential to take a role as a driving force in organic solidarity. In the industrial community in Indonesia, religion, in general, is still integrated to form a collective awareness related to honesty and perseverance in working.

Globalization and the Complexity of Meaning Solidarity. Globalization results in encounters between communities and the encounter of values that people live. After the process of globalization, the atmosphere of 
society has been very different from the atmosphere of traditional society. Globalization also encourages changes in the meaning of solidarity.

A person will only live in a limited communal (social) sphere in traditional society. In general, the social scope covers a particular limited area. The intensity of encounters in a society limited by space and time is limited in scope resulting in a strong collective awareness among the community. The solidarity that is formed becomes more solid because of the closeness and limitations of the encounter.

Globalization eliminates or diminishes the barriers of space and time that used to be the horizon limit for solidarity. As a result, humans in the era of globalization, especially in the age of advances in information and communication technology, face many value preferences. Increasingly sophisticated communicative technology allows humans to network with communities worldwide. The preference of value and the availability of communication technology have made the meaning of solidarity since globalization increasingly complex and multi-layered. The form of solidarity becomes fluid.

Previously solidarity was interpreted in the appreciation and adherence to norms, culture, and value systems in tradition. Solidarity is only formed and interpreted mechanically in village life. At this time, humans can lead a multi-layered and fluid social life. A person can be a citizen of a village, as well as a citizen, as well as a religious community, as well as staff in an office, as well as a member in a hobby community, the arts community, as well as part of fanatic fans such as dolls, as well as part of the alumni ties at school and the university where he went to education, as well as members of certain extended families, etc. In this context, solidarity is no longer interpreted singly but rather layered and mixed.

Faced with the rise of social preferences, people often experience confusion to determine the priority of roles in social life and which social communities are more appropriate to be included and prioritized. Among the many social preferences, there are also social communities that do not have a basis of solidarity or just provide a shadow (pseudo) solidarity in it. For example, often in a discussion group or game, people are usually very intense in communicating. Still, no action shows that 
the group exists in the real world. When one of its members experiences suffering, people in shadow solidarity often feel it is enough just to send a message in the form of words. Solidarity is characterized by active involvement and participation in actions aimed at the common good, and not all communities are described as such. Therefore, at this time, people need to be observant in choosing social communities that can lead to concrete solidarity.

The dynamics of fast life also mark globalization. In rapid changes due to the flow of information, solidarity can emerge quickly but can also pass soon. Information technology can help collect donations or votes when problems occur in specific communities. In this case, the encounter with the situation of suffering becomes a call for people who have sympathy and a sense of solidarity in a universal global context (human solidarity) to move. When disaster strikes, many people raise donations, leaving to volunteer to help strangers.

But globalization does not always have a good effect on solidarity. In addition to the possibility of encouraging broader solidarity, the process of exchanging information flows is also a battleground for discourse and market reduction. People are often encouraged to go with the flow and drift in without having the power to determine themselves.

\section{The Solidarity of Arek Surabaya Community}

Different from the ideas of Modern Western thinkers who see solidarity as driven by individual rational ideas, in his Javanese Ethics, Magnis-Suseno (1997) mentions that in Javanese people, sensing plays an essential role in their consciousness and becomes a driving force for various actions, including in the formation of solidarity social. This sense is interpreted actively as an intuitive sensitivity that results from "feeling in all the dimensions of both the senses of the physical body, the feeling of its position in an interaction field, a feeling of oneness with the universe, a sense of determination of its own existence by destiny, finally an increasingly deeper awareness of his own self." Taste is not just the sensory taste of a thing. Sense is a total awareness of 
the environment and oneself that guides someone to act according to the appropriate proportion in living together. This guide is not only a guide that will give salvation to himself but (and especially) gives salvation to the whole creation, which is believed to lead to a harmonious living together. Through rasa (feeling), Javanese people are directed to live in harmony with the surrounding community and nature (Magnis-Suseno, 1997).

In Surabaya's arek, the sense of giving direction to the attitudes that must be done in interacting with other people around him so that the sense can be understood as a code of social interaction that gives instructions on how to behave face to face with other people around him in order to live in harmony. Those who do not carry out appropriate attitudes in accordance with the instructions that emerge from this interaction code will not only be rejected but will also naturally feel uncomfortable with their own attitudes so that they are encouraged to take other attitudes in accordance with these sense instructions. Those who support this (or at least people who are familiar with this kind of life model) will naturally be able to grasp these forms of rejection.

In the context of the Arek Surabaya community's life, this sense as a code of social interaction fosters the ability to empathize, especially for those who have a disadvantaged fate as they have experienced various disadvantages. The sense in the Arek Surabaya community tends to interpret harmony with the people around it and nature in living together, which places equality as an essential value to be fought for in living together. For them, living together in harmony will grow when everyone is treated as an equal brother.

This attitude of promoting equal brotherhood manifests itself in a desperate struggle to show solidarity with the oppressed and disadvantaged. In the history of Indonesia, this is most evident in the actions that continue to be remembered in a monument, a gathering place, and various celebrations, namely the Ten November 1945 incident. So that thousands of Arek people died. With the multiplication and distribution of the same feeling of empathy, the arek community mobilizes stronger social solidarity because each individual directs himself to the communal brotherhood. The strengthening of arek as a metaphor 
for solidarity makes the need for heroism and sacrifice gain space and become a means of existence for Arek Surabaya.

In general, arek community solidarity through a sense of understanding that the most appropriate, healthy, and appropriate for him is not to pursue his narrow interests. In Javanese culture, this attitude is called lonely strings attached. This attitude also carries the ability to understand that everyone has their duties in the world, that the best, most calming, and healthiest for all parties is if they each fulfill their obligations. In that attitude, they have the attitude of working or "rameinggawe," which means the ability to work hard and focus on achieving the goal of living together as found in the new meaning of reality by capitalizing on their social interaction code.

In the Surabaya community in the past, the values that underpinned solidarity were manifested in the form of social attachment that made the people in it live side by side and seek mutual prosperity. Stories of the manifestation of solidarity culminating in Arek Surabaya's struggle against colonialism have been seen in the village life in Surabaya in the past, which is described as a society with high solidarity. This increased solidarity can be seen in the attitudes of members of the community who gather together every day, often helping and always showing deep concern for one another. If someone needs food for his family, his neighbor will be happy to provide the required nutrition. This kind of relationship becomes a narrative commonly found in the people of Surabaya in the past. The story of sinoman (young people community service) also manifests solidarity, whose members are young people helping people who require help.

Such solidarity is also evident in the war events in the Surabaya area. From various historical data, it appears that arek Surabaya did not hesitate to fight at the expense of body and soul to protect the welfare of its citizens. History also records that the Arek people experienced several sacrificial battles. When Mataram was about to conquer Surabaya, Arek Surabaya, by establishing cooperation with several surrounding regions, fought to defend its territory from Mataram. One of the significant battles recorded mentions how tens of thousands of Surabaya residents defended the Madura region from the Mataram forces (Trinarso, 2019). 


\section{Research methodology}

It was qualitative research using the phenomenological method since the present study dealt with cultural phenomena covered and uncovered. Phenomenology is intended to get clarity of phenomena in natural situations experienced by individuals every day. It seeks to discover, study, understand phenomena and their unique contexts experienced by individuals.

The subject of this research was the young generation belonging to the Arek Community of Surabaya across generations. The setting of the study was Surabaya City, where the subjects were born and spent their lives. They were randomly selected by considering their age and intensity of living in certain areas in Surabaya.

There were two kinds of data analyzed in this study: descriptive and reflective. The descriptive data were in the form of field notes obtained during in-depth observation and interview. The reflective data were the interpretation of the idea behind the descriptive ones. The reflective data were deduced from the interpretation of the field notes combined with the result of forum group discussions with experts and Arek Surabaya activists.

Thus, direct observation and in-depth interviews with subjects across generations of the arek community were done to obtain the expected data. Various group discussions with community activists and intellectuals who studied Arek Surabaya society were conducted to verify the data.

\section{The Findings}

\section{Solidarity Shift}

To achieve comprehensive findings, three processes of activities were conducted. The first process was done by literature observations and field surveys using interviews with Surabaya residents who were randomly selected in several districts that we classed as the initial village of Surabaya. The aim was to find citizen involvement in maintaining 
the solidarity of the people of Surabaya. In the second process, a group discussion with several experts was conducted to understand their opinions in assessing community solidarity. The third process was carried out by conducting empirical observations in the field of the data obtained in the two previous processes. Here, we went back into several areas in Surabaya based on some data we obtained in the previous process.

Through literature reviews, observations, and theoretical discussions, it has been found that the solidarity of the Arek Surabaya community is not an astatic entity but dynamic and is still in the process of formation. And based on the in-depth observations and interviews carried out and the result of group discussions with experts, the study uncovered a directive change of solidarity. Since the reformation era, the solidarity of arek Surabaya communal life has shifted from heroic solidarity into non-heroic solidarity. This shift of solidarity can be mapped into the following categories.

\section{In the commercial building areas}

Solidarity tends to be threatened in areas full of commercial buildings (lighthouses). This happens because the economic center building is built primarily by calculating the capital and investment sides only without regard to the cultural and sociological situation of the community. Even if this cultural and sociological situation is considered, in general, that consideration is only used to achieve the interests of capital. Furthermore, in general, the economic center building does not attach importance to their involvement in the concerns and problems of the community around the financial center building they founded. In this case, the conflict between the economic center building and the surrounding community becomes very vulnerable even though they are proud of the large buildings around them. Following Durkheim's ideas, solidarity in this region tends to move from mechanics to be more organic. In the context of Arek Surabaya, people around the Bubutan area and Sepat reservoir area tend to have this characteristic of solidarity. 


\section{In the non-commercial building areas.}

In areas with no economic buildings, solidarity tends to remain strong. In this case, we find that there is no significant threat to community solidarity even though, around the community, several horizontal buildings have been built as places of business. This happened because, in general, investors were not aggressive enough to control the land around them that harmed other communities. In some areas, it even appears that the involvement of the "small investors" is felt by the surrounding community both in providing jobs and in various other forms of involvement to maintain community solidarity. In such areas, the people's solidarity tends to remain mechanical with the cultural situation of Arek Surabaya as the basis for solidarity formation.

\section{In the religious villages}

In an area of a village close to a particular religious center, solidarity remains strong as the religion provides spaces for shared life. In this case, the manifestation of solidarity has changed not only in the form of culture but in the form of religion. The practice of togetherness in the faith of people who live in this kind of area strengthens solidarity between them. In such places, the people's solidarity tends to remain mechanical. Still, the basis for the formation of solidarity is shifted to no longer be culturally characterized but driven by religious sides that are integrated with the social, cultural characteristics of the people. In the context of Arek Surabaya. The arek community in Gubeng Mosque and Ampel areas tend to have this kind of solidarity. Mechanic solidarity colored by Islamic tradition is maintained.

\section{In the traditional village}

Communities in the traditional village still maintain the mechanical solidarity that unites communal life. The spirit of village life with high solidarity is also maintained and preserved in some areas, such as in the old village of Maospati or in Tambak Bayan. The 
spirit of the village can survive through many joint activities between residents.

\section{Sentimental solidarity}

In addition to solidarity within the village, solidarity based on sentimental identity (bonek, nationality, religion) also emerged. In addition, several villages are increasingly fading in solidarity because they are influenced by capitalism. In some areas, such as Bubutan and Sepat, sentiment and solidarity cannot unite the community. They tend to focus on economic capital. Societies that are more interested in economic pursuit tend to become more individualistic. In the pursuit of the economy, the problem is that people are often faced with a large capital force. Faced with stronger economic capital owners, they lost the "fight." Defeat in the battle of capital makes a person occupy fragile places (life is poor) in the economic chains. Meanwhile, no other root sentiments (value/cultural systems) can strengthen their solidarity (more individual and transactional). In other societies, even though the power of capital enters and influences the community, the community can still interact with one another. Relations between communities do not become transactional or merely transactional.

\section{Factors affecting the Solidarity shift among arek Surabaya}

There have been many factors that spring this solidarity shift. At present, the cultural conditions that the Arek people in the past have attempted have been eroded by time. Massively, this happened in the period after the 1998 reforms that hit Indonesia as a whole. This occurs because capital flows transform the way people think in such a way that influences their relations with members of the community. Because of this economic interest, the community's tendency to simply gather and chat with each other is increasingly replaced by other attractions that have economic characteristics. This does not mean that to maintain Arek culture, financial capital must not enter Surabaya. In observing the development of Arek Surabaya, this era is no longer the right time 
to just carry out physical struggles over concrete things just like that. However, what is more important, is that there is an awareness of cultural wars, which will significantly affect the flow of material development. That is, Arek Surabaya, as a culture that lives and develops in the second metropolitan city, basically has always been understood to experience various threats to be dominated by the way of life and development of other cultures.

In the Surabaya communal life today, cultural conflict is inseparable from the process of globalization that puts communication technology as the primary weapon. Along with such a massive movement of capital into Indonesia, the culture of Arek Surabaya underwent a shift in meaning which in turn would change the way of thinking and the way to behave.

Various developments in the Arek area of Surabaya carried out with a material economic approach often present the anxiety of small communities living in the area that will be used as the center of economic development. This is related to the money paid for compensation payments because their land will be taken over by investors. This approach model, which merely emphasizes material economy, often produces family conflicts and damages good solidarity relations between neighbors. This makes people who initially care for the people around them become only concerned with economic issues. In this condition, the meeting with other people around him is considered not too important and what they think about then is just a matter of how they make money. Here, solidarity experiences a shift in meaning. Regarding this cultural war, it appears that the Arek cultural community is a situation of globalization that makes it prone to being abandoned by young people. This will change the assessment of what is essential or appropriate and what is not essential or appropriate for them. This happens because arek culture is considered unpopular, which is unassay about preserving by young people, so it is appropriate to be slowly abandoned. Therefore, it is necessary for those commented to preserve this local culture. The data collected has indicated that there has been some kind of disharmonious relationship between the high and the low economic capital owners. In some places, housing estates in Surabaya are indeed 
built close to the village area. Even the big, tall, and big buildings built were located not far from the villages. It is certainly not always apparent that it can be narrated with adequate recognition by citizens. Still, if it is examined further, it will appear some kinds of conflict and hostility between those who are rich and those who are poor. As a result, they do not know each other, or in other words, solid relation among them has faded out. There is a shift of solidarity among the have and the poor. There is a gap between them.

On the one hand, the spirit of solidarity is a stall in the people's hearts; on the other hand, because of work, they cannot do this due to time constraints. As a result, a kind of hybrid solidarity has emerged. This hybrid solidarity is demonstrated through interconnected activities between transactional and interaction they have created. Members of the community still gather and have interaction one into another at the time of death, wedding parties, cooperation, and village events (as characterized by mechanical solidarity), but at the same time, they are very transactional in their way of life, especially in work systems that are increasingly disaggregated (organic). The government needs to act more closely in relations between the people around big capital and the owners of big capital. The government must realize the importance of solidarity for the survival of the Arek Surabaya cultural entity. Here, the government needs to care more about the people.

Another factor found related to the shift of solidarity in the Arek Surabaya community was the understanding of the community, which was very much apparent as not being literate enough in understanding the development of life together in Surabaya. Almost all community members in the area in the village were obliged to do so just because they were ordinary neighbors when they met and gathered frequently.

From their answers to the various questions proposed, the study revealed that they were quite innocent of what solidarity is and why it is essential to growing in their community life as fellow members of the community. Therefore, it is urgent that solidarity as a value needs to be developed together as the Arek Surabaya community. As a result, the Arek Surabaya community does not have a reflective ability to respond 
to various cultures that accompany the capitalization of multiple processes of living together. Faced with the condition of the people who are in a battle of cultural influences, most members of the Arek Surabaya community do not have enough capital to remain strong in maintaining their culture. Low critical thinking tendencies (critical thinking) have made them easy to carry it out anywhere.

\section{Discussion of Findings. Solidarity Shift and the principle of "rasa"}

Rasa is prominent in Javanese life and is highly valued. In the most common life, "rasa” means taste or feeling. Mystically and practically, it is the intuitive inner feeling, which is the property of every person (Mulder, 1994). Rasa is the instrument leading to true insight in life (Mulder, 1994). In Javanese thinking, rasa often contrasted to "akal" or reason, the instrument for understanding reality, the phenomena of the world, and everyday affairs (Mulder, 1994)

In the past, communities in Surabaya villages interpreted solidarity in the "rasa" principle. "Rasa" is lived by the community as an encouragement to act for the community. Life in the village is characterized by a community that has a "rasa" awareness forming attitudes to help one another, struggle together to overcome life's challenges and work for the common good. Forms of solidarity tend to be mechanical because society is driven by a collective consciousness that is more or less the same and encompasses the whole way of life of the community.

The present study uncovers that solidarity can experience a shift in meaning. The meaning of solidarity will also affect people's behavior and social ties. The encounter with industrialization and capitalism is a factor that is enough to influence the shift in solidarity. The entry of large investments into an area (Surabaya) has changed people's livelihoods. More and more people are working in the capitalist industry, making society interpret work differently. In a capitalist society, society works to achieve economic prosperity. Work is not a social value but an individual. People who work like this often lose time gathering and building solidarity as in the past. 
Many social theorists, such as Durkheim and Habermas (Ritzer, 2017), are very worried about the increasingly fading solidarity in modern industrial society. People can truly become aware that they live together with others in a social community through community solidarity. In Surabaya society, researchers found that in a society influenced by capitalist society, solidarity is not lost but is interpreted by the community differently. In today's society (especially in Surabaya), the form of solidarity is no longer singular and mechanical or merely organic. The form of solidarity in today's society is liquid solidarity. Society interprets solidarity in the mixes that are the consequences of its multi-layered social life, and it is recognized as having a fluid nature in several contexts.

Based on the literature reviewed, observations, and theoretical discussions, it has been revealed that the solidarity of the Arek Surabaya community is not an entity that is permanently fixed but dynamic and is still in the process of formation. In this case, we went through three processes in this research. The first process we went through with theoretical observations and field surveys using interviews with Surabaya residents who were randomly selected in several districts that we classed as the initial village of Surabaya. The aim is to find out how much citizen involvement is to maintain the solidarity of the people of Surabaya. In the second process, we conducted a group discussion with several experts to understand how the experts' opinions in assessing community solidarity. Discussion materials are the first process of research. The third research process is carried out by conducting empirical observations in the field of the data obtained in the two previous processes. Here, we go back to some areas in Surabaya based on some data we obtained in the previous process.

In the initial research process focusing on theoretical and empirical observations in several "ancient" areas in Surabaya, before the colonial period, more or less in the 17th century, solidarity among the Kingdom's political prisoners gave birth to resistance to the Kingdom of Mataram. Entering the colonial era, solidarity between Arek Surabaya was manifested in anti-colonial and anti-Japanese militancy. While maintaining independence, Arek Surabaya's solidarity made them known as the most persistent fighters defending Indonesia. In this case, we see that 
solidarity among the Arek-arek Surabaya in this period was driven more by friendship as part of human social nature. Personal relationships between and among individuals characterize such friendship.

The form of arek Surabaya solidarity has been maintained for decades and now shows one of its faces in their daily lives in the native villages of Surabaya. The idea of modern solidarity seems to color the notion of solidarity today. Solidarity is no longer based on personal ties because it is "not feeling good" or "sungkan" (reluctant) or feeling unassay as Mulder (1994) describes if they are not involved in the activities of living together but rather the bonds of shared interest that are formed in such a way for a particular interest. Involving in social activities or events may strengthen the system of building solidarity of living together such as, in the social field, namely community meeting, independent day commemoration, youth organization, sinoman groups, community services, and dividing rice packets. In the religious contexts, solidarity is manifested in a committee of ketupatan, Islamic discussion, takbiran, recitation, and village worship. In the field of education, solidarity is manifested in teaching early childhood students and holding night markets.

When surveying people in the six districts of Surabaya, it has been found that even though all the residents said that they were still active in joining activities, undeniably a few of them cannot or choose not to be active in joining social activities because they are busy at work, feeling of reluctant never exist among them. The excuse for not being involved in joining activities, the idea of alienation of workers in capitalist industrial society seems relevant to today's situation. Works have made people alleviate the social world. The demands of work and the benefits obtained through successful meeting targets have raised the tendency to limit social life with the surrounding environment.

In addition to undergoing joint activities, solidarity within the Arek Surabaya community is also realized by respecting and acknowledging the "other" existence. This "other" existence, for example, is the presence of people from other ethnicities such as Chinese, Madurese, and Malang in their neighborhoods. Generally, Arek Surabaya is ready to accept and build solidarity with different ethnicities such as Chinese, 
Madurese, and Malang. The public indeed knows common stereotypes to each of these ethnic groups; for example, the Chinese are less able to blend in, distance themselves from the non-Chinese population, are rich, and excel in employment and education. Likewise, with the Madurese ethnic group, there is a common stereotype that Madurese prefer to gather with ethnic siblings, not keeping clean or rude. However, this stereotype is not necessarily accepted by the public. From our observations, we find that these stereotypes do not appear to affect Arek Surabaya's personal relationships with others outside his community. For Arek Surabaya, the thing that comes first in relationships is the willingness to adapt and behave well towards the people around him. The ability to surpass common stereotypes shows that the egalitarian nature of Arek Surabaya and respect for fellow human beings as humans are still maintained to build solidarity.

A similar situation is also evident in Arek Surabaya's attitude towards those from higher or lower economic status groups. In our observations, for rich or super-rich people, Arek Surabaya generally does not experience problems as long as the person wants to blend in and have good empathy and solidarity. Members of the Arek Surabaya community regard richer people as a blessing because they can help the people around them, as a personal right to own more wealth, and as a result of their hard work. Once again, even though there is a negative view of the rich, like the rich are arrogant and care about themselves, this view does not significantly affect relations with people who are richer. Residents will see the rich person well if the rich people want to be involved in joint activities in the village, for example, in devotional work activities. This view that goes beyond this general stereotype shows that the Arek Surabaya community recognized and respected the existence of others.

In this case, one form of solidarity is self-involvement, which is an action that does not stop at sympathy but takes real effort. Selfinvolvement can be seen from Arek Surabaya's attitude towards poor members. With respect to the "poor," Arek Surabaya does not only stop with sympathy, which is feeling sad and concerned but also empathy by helping the poor. 
From the observations above, Arek Surabaya solidarity values still seem to be preserved by the people of Surabaya in general. However, the level of solidarity has shifted. Arek Surabaya's solidarity is not meant as a call of feeling (feeling) that moves Arek Surabaya to act for others but merely as an interest that matches other interests. One of those interests is the economic motive that drives them to solidarity with other people around them. This motive also makes Arek Surabaya willing to accept anyone different from them to the extent that acceptance, prosperity, harmony in living together can be achieved. The narrowing of the meaning of solidarity is in line with how the post-reformation situation in 1998 changed the socio-political life in major cities in Indonesia. According to Munafrizal (2005) in Lane (2009), the reformation era is an "Era of transition, followed by political liberalization, (which) has transformed Indonesian society drastically.” Indonesian people in the New Order era (before the reformation) felt enormous pressure in voicing their opinions; now (after the reform) they can freely articulate their opinions and political views. The opening of democratic taps in the post-reform era brought about the restructuring effects of the often corrupt government bureaucracy and the negative effects resulting from meeting various diverse ideologies and values in everyday life.

\section{Conclusions}

After the reformation, the condition of the people of Surabaya has changed. Large capital is more intense in Surabaya. In effect, many regions that were not previously economic centers were directed to become financial centers.

In the present-day Surabaya community, solidarity is no longer based on fighting against invaders but on prosperity. Solidarity is raised in activities to get together, hang out, convoys, picnics, and walks together. In these activities, solidarity seems to be the goal. Whereas in the past of the Surabaya community, solidarity was placed as a means for a specific purpose, fighting the invaders of peace and national independence. The form of bonek or stubborn concept is an indication that solidarity 
is the goal. Solidarity among Surabaya people today is directed at creating certain sentiments bonek is the most prominent group among arek Surabaya. Religious groups and groups of certain hobbies like fighting ducts also tend to sentiment identity. For this reason, it is believed that there is a shift in the concept of solidarity among arek Surabaya.

The study also uncovered that Rasa, as the basis of solidarity, experienced turmoil with a new form of development of economic centers. Some financial centers no longer emphasize rasa-pangrasa in developing their economy. Capitalistic tendencies that prioritize capital interfere with solidarity running based on this rasa. People who stress this sense of solidarity generally experience marginalization because their energy must be supplied by an increasingly lost encounter in a capitalistic society. As a result, those who prioritize this rasa solidarity must form new solidarity characterized by hybrids: rely on (expect) encounters and understand the capitalistic characteristics of the societies that hit Surabaya. On the other hand, the owners of capital need to increasingly contribute dialogically with the community and culture not to negate each other. Capitalism will only create an individualistic society that is counterproductive to the people of Surabaya and capitalism itself because the common good in the context of Surabaya cannot be carried out based on individualism. On the other hand, prosperity as an objective of the economic struggle of the people of Surabaya in the contemporary era is impossible to be pursued without giving room for capital to enter Surabaya.

There are two main factors that cause a shift in the meaning of solidarity and its implementation among arek Surabaya. First, investment policies that are not balanced by a cultural approach promoting encounter contribute to living together and dialogue. Everything starts from the capital for the sake of greater capital, and the rationality developed here is merely economic rationality. Second, globalization with information flows makes social preferences more layered. In this context, solidarity is interpreted as liquid solidarity (hybrid) according to the role in complex social life.

Arek Surabaya, who were not well informed of globalization, struggled for cultural modernization. This makes Arek Surabaya unaware 
of the importance of maintaining the existence of their culture for the values that they have held fast. The lack of literacy also risks the community's resilience as an interdependent community.

\section{Abstract}

\section{Hybrid Solidarity Arek Surabaya Solidarity Shift in the Post-Reformation Era in Indonesia}

This study tried to uncover the solidarity shift of young people of Surabaya nicknamed "arek Surabaya" after the reformation era in Indonesia. The study was based on the assumption that solidarity is not static but dynamic. It is hypothesized that the solidarity has undergone some kinds of reformation era in Indonesia in 1998, after the fall of the new regime. It is also believed that social and political changes significantly impact the social solidarity to change. To obtain the research data, a phenomenological method was utilized. The subjects of this research were people belonging to the Arek Community of Surabaya. The location of this research was in the old villages of Surabaya City. An in-depth interview with the subjects and forum group discussion with people knowledgeable of the arek Surabaya community were conducted. Based on the data obtained through interviews and forum group discussion, the research revealed that the condition of the people of Surabaya has changed after the reformation. Large capital is more intense in Surabaya. In effect, many regions that were not previously economic centers were directed to become financial centers. Keywords: Arek Surabaya, community, solidarity, transformation, Reformation Era

\section{References}

Bayertz, K. (1999). Solidarity. Kluwer Academic Publisher. https://doi.org/10.1007/ 978-94-015-9245-1

Derpmann, S. (2009). Solidarity and Cosmopolitanism. Ethical Theory and Moral Practice, 12(3), 303-315. https://doi.org/10.1007/s10677-008-9150-6

Durkheim, E. (1984). The Division of Labor of Society. Macmillan Press. https://doi.org/ 10.1007/978-1-349-17729-5

Lane, M. R. (2009). Mass Mobilisation in Indonesian Politics, 1960-2001: Towards a Class Analysis. University of Wollogong.

Magnis-Suseno, F. (1997). Javanese Ethics and World-View: The Javanese Idea of the Good Life. PT Gramedia Pustaka Utama. 
Mulder, N. (1994). Individual and Society in Java. A cultural analysis. Gajah Mada University Press.

Munafrizal, M. (2005). Gerakan Rakyat Melawan Elite. Resist Book.

Ngadiman, A. (2008). Patterns of Javanese Rhetoric in Various Settings. Penerbit Laros.

Palmos, F. (2016). Surabaya 1945, Sakral Tanahku. Obor Indonesia Foundation.

Trinarso, Agustinus Pratisto. (2019). Nilai Egaliter Arek Suroboyo Dalam Perspektif Aksiologi Dan Kontribusinya Bagi Penguatan Budaya Lokal Di Indonesia. Gajah Mada University.

Ritzer, G. (2007). Contemporary Sociological Theory and Its Classical Roots. Mcgrow Hill.

Ritzer, G. (2017). Teori Sosiologi. Dari Sosiologi Klasik Sampai Perkembangan Terakhir Postmodern. Pustaka Pelajar.

Pasaribu, Saut. (2012). Eight Edition Sociological Theory. Student Library.

Sholihatin, E. (2013). "Apakah Pisuhan Selalu Bermakna Negatif? Fungsi Pisuhandalam Masyarakat Arek dan Masyarakat Mataraman.” Mozaik, 13(2), 158-167.

Thijessen, P. (2012). From Mechanical to Organic Solidarity, and back with Honneth beyond Durkheim. European Journal of Social Theory, 15(4), 454-470. https://doi.org/ 10.1177/1368431011423589 